\title{
DEVELOPMENT OF THE INSTITUTIONAL FRAMEWORK OF PUBLIC- PRIVATE PARTNERSHIP IN THE REPUBLIC OF SERBIA
}

\author{
Goran Amović \\ Agency for Business Advisory Services „CONSECO“, East Sarajevo, \\ Rebuplic of Srpska, Bosnia and Herzegovina
}

g_amovic@yahoo.com

\begin{abstract}
In present-day conditions of global economy, the processes of development of national economies require the need for capital investments in the development and improvement of public infrastructure, and the provision of public services in the field of general social activities (education, health care, culture, sports) and social issues. The demand for a better infrastructure and more efficient public service, with public sector constraints, requires a new role of public sector, a new approach and new strategies. In the context of the above mentioned, Public-Private Partnership (PPP) establishes an innovative framework for more efficient implementation of public investments faster construction, lower costs, optimal risk allocation, more efficient management, better public services, etc. In this paper we will present the most important characteristics of the Public-Private Partnership model, with a view to the chronological development of PPP institutional framework in the Republic of Serbia.
\end{abstract}

Keywords: Public-Private Partnership, public sector, investments, financing, infrastructure.

\section{Introduction}

In the last decade of the $20^{\text {th }}$ century, the Republic of Serbia was in transition from one social and political system to another. In the time of a turbulent political environment, unsuccessful privatizations, changes in the ownership structure, the destruction of the economy, and devastation of public infrastructure have happened. The reforms that took place in almost all areas of social life significantly slowed the economic development of the country. These aspects were reflected in the fact that Serbia has, just in recent years, been developing its network of highways, attracting investors and facing numerous unresolved infrastructural issues of its largest cities. In order to overcome these problems, significant financial resources are needed, which the public sector currently does not have. For effective revitalization of the public sector infrastructure and services, it is necessary to provide new strategies for attracting capital and involving the private sector in the financing of public investments. Public-Private Partnership represents an innovative form of private capital investment in financing investments in the field of public services, building infrastructure and other public goods in order to meet public and social needs."Due to the limitation of budgetary resources, PPP appears as a model that creates faster assumptions for the quality provision of public services and the satisfaction of public needs" (Savanović, 2009).

\section{The concept and models of Public- Private Partnership}

Although there is no single definition, all Public-Private Partnership interpretations have certain common characteristics: Public-Private Partnership refers to the cooperation of two or more entities, of which at least one is a public entity; partnership between the public and the private sector is a long-term partnership (mainly 25-30 years); public and private sector entities integrate financial and knowhow resources; risks and responsibilities in a partnership are distributed in a way that each subject is assigned with the bestmanageable risk. 
PPP has a large number of interpretations, and can be organized in many ways and established in various economic and noneconomic activities. The World Bank defines PPP as a "long-term contract between a private party and a government entity for providing a public asset or service, under which the private party bears a significant risk and management responsibility, and where payments received are linked to performance". The Organization for Economic Co-operation and Development (OECD 2012) defines PPP as a type of contract where a private investor provides the services and infrastructure normally provided by the public sector. According to Ostř́žžek et al. (2007), "PPP is a contractual partnership between the public and private sectors that leads to the delivery of public infrastructure and services, using the capabilities of both partners with the most appropriate allocation of resources, responsibilities, risks and associated revenues".

According to the Green Paper on PublicPrivate Partnerships and Community Law on Public Contracts and Concessions (European Commission Communication COM 327 Final 2004) the two basic forms and modalities of Public-Private Partnership can be distinguished:

- Contractual PPP, where partnership between the public and the private sector is based exclusively on the contractual relationship;

- Institutionalized PPP, where partnership between the public and private sector is realized through the establishment of a joint venture.

The contractual PPP is implemented in a way that the private partner provides immediate service to the end users, with the supervision by the public sector. The basic characteristic of the contractual PPP is the method of concessionaire's remuneration, 82 which consists of a fee paid by the endusers of services along with additional subsidies from the public sector (if provided by the contract). The most prominent example of the contractual form of PPP is the establishment of a Private Financial Initiative (PFI), a modality developed and perfected in the UK, which was upgraded in 2012 through PFI 2. Through the PFI and PFI 2 models, the United Kingdom has built and reconstructed dozens of schools, hospitals and other social and public infrastructure constructions. In this model, private partner compensation does not have a form of compensation paid by the end user for the use of a constructions or services, but a regular payment is made by the public partner. These payments may be fixed, but can also be calculated using variables, e.g. based on the availability of the construction and/or services, or even the levels of use of the construction.

The institutional form of PPP involves the establishment of a joint business association from public and private sector for the purpose of implementing a particular public project or providing a public service. This form of PPP can be realized by establishing a new institution or by taking over the share and control in an existing public institution by a private partner. The institutional form of PPP has its application dominantly in the field of public services that can be of great importance to the public sector, which requires that the public sector retain part of the control and supervision of the provision of services (e.g., traffic infrastructure, water supply, electricity supply, etc.).

Depending on the degree of involvement of the public and private sector in design, construction, financing, maintenance and management, it is possible to distinguish several basic models of Public-Private Partnership. 
The traditional PPP model - BOT (buildoperate-transfer) is characterized by the fact that in this contract, the private entity assumes responsibility for building (B) and operating $(\mathrm{O})$ assets. After construction, the private sector has a contractual obligation for long-term facility management, and this model aims to motivate a private partner to manage cost efficiently at an early stage of construction in order to maintain optimum maintenance costs during the facility's utilization. BOT projects are usually large, greenfield infrastructure projects that would otherwise be funded, built and managed exclusively by the government in a traditional public procurement system.

DBFO (design-build-finance-operate) is the most commonly used PPP model that allows the private sector to design, finance and build the public good, to take the public good into the long-term lease and manages it (to earn income in contracted period), and after the lease is expired to transfer the public good to the public sector.

The most common other models are:

- Maintenance \& Operation Contract (OM); In this model in accordance with the signed contract and under certain conditions, a private company manages public property, which still remains state-owned.

- Build \& Own and Operate (BOO); The private sector finances, builds and manages the public good of which it is the owner.

- Build \& Own\& Operate \& Transfer - BOOT; The public sector grants a franchise to a private company to finance, design, build and manage public good, as well as the right to charge for its use over a period of time, after which the ownership over the public good is hand over to the public sector.
- $\quad$ Buy \& Build \& Operate - BBO; The public sector transfers public property to a private (or mixed) entity that improves and manages public property for a certain period of time.

- Operation License; Is often used in IT projects when a private company obtains a license or the right to provide public service over a specific period of time.

\section{Risks of Public-Private Partnership}

One of the characteristics of Public-Private Partnership is the concept of risk sharing and the general principle is that the largest degree of risk is being borne by the project partner that at the same time has the largest share on the project's management (Bovaird, 2004). Each PPP project has its specific risks. According to Moralles et al. (2009): "risk $=$ consequence $\mathrm{x}$ probability of occurrence". The key to a successful PPP project is to find a balance in risk sharing between the public and private partners in relation to the Value for Money (VfM). Grimsey and Lewis (2004) indicate that an optimal risk allocation is aimed at minimizing the chances for risk occurrence and the consequences that risks can potentially produce. Akintoye et al. (2003) state that risk transfer is one of the ways to achieve VfM, but based on the optimal (not total) risk transfer. As a general rule, it can be expected that VfM will initially increase in the event that the risk is transferred to the private sector until an optimal point is reached at which all risks are assigned to the partner best able to handle the risk.

The equation below illustrates the theory according to which the obtained Value for Money is directly dependent on the price of the bid and the value of the transferred risk. 
Public sector VfM ${ }_{(\max )}=$ bid price $_{(\mathrm{opt})}+$ value of transferred risk $_{(\mathrm{opt})}$

The higher the demands of public sector for a private partner to take more risks, the higher the price of the bid, but the overall exposure to the risk of the public partner will be reduced. The maximum VfM will be achieved where the risk distribution is balanced between the two entities that can best manage the risk and provide the best VfM of the project.

Value for Money - VfM is used as a criterion that combines quantitative and qualitative analyses in order to determine how the project is financed, or choose a model that will provide the highest value in relation to the money invested. The purpose of VfM analysis is to inform the public sector about whether the proposed projects will be realized as a PPP or as other, more traditional, form of public procurement. For this purpose, VfM analysis usually involves a combination of qualitative and quantitative analysis (World Bank, 2013). The quantitative component includes those project factors that can be expressed in monetary terms. The quantitative assessment is using the Public Sector Comparator (PSC) which examines whether the private funding proposal offers greater Value for Money compared to the traditional way of financing. The Public Sector Comparator analyses the present value of the total living costs in the contracted period of the project according to the traditional financing model (public procurement) in relation to the same type of costs incurred in the PPP arrangement. Delivering the optimum Value for Money (VfM) means that the PPP arrangement will provide the lowest level of costs (in line with the specified requirements for the quality of the public good/service and risks) over the entire life cycle compared to the traditional method of public procurement.

\section{Development of Public-Private Partnership in the Republic of Serbia}

Public-Private Partnership places its role between the traditional way of performing public affairs (public procurement, establishment of public companies, contracting services, contract management, leasing, etc.), where the responsibility and risks in the process of financing, construction and management of a public facility are taken by public sector, and full privatization - when all these activities are carried out by the private sector, after the sales process and the takeover of control in a public company.

Prior to the entry into force of the Law on Public Private Partnership and Concessions in November 2011, the area of publicprivate partnership in the Republic of Serbia was regulated by a large number of individual regulations that regulated the key issues in different ways. The first version of the Concessions Law from 2003 envisaged a complicated and lengthy procedure for awarding the concession, which, in the end, resulted in unsuccessful attempts to establish a Public-Private Partnership. Out of several concession agreements in the field of mining and construction of highways, the majority were unsuccessfully implemented and contracts were terminated. Regarding the local level, private sector investment in infrastructure was carried out in accordance with the Law on Communal Activities from 1997, which allowed that the execution of communal activities could be entrusted to a third party outside the public sector. This Law was the basis for most Public-Private Partnerships implemented at the level of local selfgovernment in Serbia, mostly in the area of maintaining cleanliness and waste management. The Law on Public-Private Partnership and Concessions from November 2011, together with the Law on Communal Activities and the Law on Public Procurement, established a new system framework for the implementation of the Public-Private Partnership project. 
The Law on Public-Private Partnership and Concessions regulates: conditions and manner of drafting, proposing and approving Public-Private Partnership projects; rights and obligations of public and private partners; the competence of the Commission for Public-Private Partnership; conditions and manner of granting concessions; subject of the concession; legal protection in procedures for the award of public contracts, as well as other issues. In accordance with this Law, the PublicPrivate Partnership implies long-term cooperation between public and private partners in order to provide financing, construction, reconstruction, management or maintenance of infrastructural and other facilities of public importance and provision of services of public importance, which can be contractual or institutional.

The improvement of the legislative framework for the development of PublicPrivate Partnership continued with the adoption of the Law on Amendments to the Law on Public-Private Partnership and Concessions ("Official Gazette of the Republic of Serbia", No. 15/2016) on February 24, 2016, by the National Assembly of the Republic of Serbia, which officially came into force on March 4, 2016. This Law harmonized the regulations with the latest requirements of European legislation in the field of Public-Private Partnership. It also strengthened the role of the Ministry of Finance in the procedures for implementation of Public-Private Partnership projects with and without elements of the concession. The Commission for Public Private Partnership, established in 2012, as the central regulatory body of public administration in charge of PPP, is directly involved in the phase of approving PPP projects and concessions. The project cannot be implemented as a PPP or concession without a previously obtained positive opinion from the Commission. In order to approve it, it is necessary that the PPP project or concession have the majority votes of the members of the Commission along with the approval of the representatives of the Ministry of Finance within the Commission.

In the process of approving PPP projects and granting concessions, the Commission for Public-Private Partnership under this Law is responsible to:

- Provide support in drafting PPP projects or concessions;

- Provide necessary information and consultations on PPP issues;

- Provide an opinion in the process of approving PPP projects or concessions;

- Ensure the application of best international PPP practices;

- Develop and improve methodological materials;

- Cooperate with other public institutions and non-governmental organizations; and

- Give recommendations for improving projects at the request of the public sector.

The chronological development of the institutional framework of the PPP in Serbia can be presented as follows (European PPP Expertise Centre, 2014):

- 22 November 2011 - Established Law on PPP and Concessions;

- 24 November 2011 - Established Law on Public Utility Activities;

- 9 February 2012 - Establishment of the PPP Commission;

- 29 December 2012 - Established Public Procurement Law;

- 29 May 2013 - Established Regulation on the Supervision of Implementation of the PPP Public Contracts; 
- 27 June 2013 - Established Ordinance on Keeping and the Content of the Public Contracts Registry;

The improvement of the legislative framework for the development of PublicPrivate Partnership continued with the adoption of the Law on Amendments to the Law on Public-Private Partnership and Concessions officially on 4 March 2016.

The Commission for Public-Private Partnership, as a body of the Government of Serbia in charge of approving PPP projects, for the past seven years of its existence, gave 112 positive opinions regarding proposals for PPP projects with or without elements of the concession (Commission for Public Private Partnership of the Republic of Serbia 2019). The dominant number of submitted project proposals came from the field of regulating urban and suburban transport of passengers, municipal waste management and reconstruction of the public lighting system. A small number of projects dealt with the design of public parking, road construction and maintenance, the reconstruction of the heating system, the use of renewable energy sources, while the interest in projects in the field of education or health is still underdeveloped for the time being.

In 2015, the City of Belgrade started a capital project for municipal waste treatment and solving the ecological problem of Vinča landfill, which obtained a positive opinion from the Commission for Public-Private Partnership of the Government of the Republic of Serbia. At the end of 2017, the representatives of Belgrade's city authorities signed a PublicPrivate Partnership contract with the Consortium comprised of the French company Suez Groupe S.A.S. and the Japanese Corporation Itochu IEnvironment. This 25 years long contract stipulates that in the first phase of the project, the closure and clean-up of the Vinča landfill should be carried out. In the second phase of the project, the construction of a cogeneration plant for generating energy in the form of heat and electricity from non-recyclable waste is planned. The total investment amounts to EUR 300 million, with the completion date in 2021. It is planned that the plant will annually process 340000 tons of waste, with a capacity of $25 \mathrm{MW}$ of electricity and $56 \mathrm{MW}$ of thermal energy. This project is considered the most important infrastructure project of Public-Private Partnership in the Republic of Serbia.

We can say that the Republic of Serbia recognized Public-Private Partnership as a development opportunity and a way to improve the quality of public services, revitalize existing and build new infrastructure, and that there are several examples of successfully implemented projects according to the Public-Private Partnership principle in this country.

\section{Final considerations}

In the first part of this paper, from the theoretical point of view, we considered the most important characteristics of the Public-Private Partnership model, with particular reference to forms and models of Public-Private Partnership, as well as risks and Value for Money. In this regard, we presented an overview of the main attitudes and perceptions in the works of the leading authors in the field of Public-Private Partnership.

In the second part, from the theoretical aspect, we considered the chronological development of the institutional framework of the PPP in the Republic of Serbia. In the last several years, significant breakthroughs have been made in the implementation of PPP projects. 
Clearly articulated structures for monitoring and support of the implementation of PPP projects, along with an adequately designed PPP legislative framework and the support of the central PPP unit, contributed to the efficient development of the potential of Public-Private Partnership. In the analysis of the development of the European PPP market for the period 2014-2018, the European Public-Private Partnership Expert Centre (EPEC) notes that in the mentioned period Serbia achieved the value of PPP projects in the amount of EUR 350 million, which, according to the same author, place Serbia in the same category as Austria, Poland, Finland (EPEC, 2019). This can lead us to conclude that Serbia is on the right track in these first years of implementing this system, and that the efficiency of the Public-Private Partnership process can be assessed as successful.

This research can serve as a backbone and a handbook for further research that will evaluate opportunities and offer a solution to build an efficient and functional PublicPrivate Partnership system in countries that are in the initial phase of its implementation.

\section{Literature}

1) Amović, M., Ivanić M., Slijepčević Đ. 2014. Javno-privatno partnerstvo i koncesije: teorijski aspekti $i$ primjena koncepta, Banja Luka : Grafid, 2014 (Banja Luka : Grafid). ISBN 97899955-89-31-8.

2) Amović, G. 2017. Efficiency of PPP implementation in Bosnia and Herzegovina,
Istočno Sarajevo: Zbornik radova Ekonomskog fakulteta u Istočnom Sarajevu br.15, str. 49-54.

3) Benković S. 2011. Efikasnost primene javnoprivatnog partnerstva na unapređenje infrastrukture. Management - časopis za teoriju i praksu menadžmenta, Godina XVI, Broj 58, Mart, str. 37-42, ISSN: 0354-8635.

4) Brzozowska, K. 2006. Advantages and Threats of Public-Private Partnerships in Larger Infrastructure Projects, Warszaw: CeDeWu.PL.

5) Savanović, S. 2009. Finansiranje lokalnog razvoja. EDA, Banja Luka.

6) Gazivoda, J. 2019. The Public-Private Partnership Law Review - Edition 5. The Law Reviews.

7) Commission of the European Communities. 2004. Green Paper on Public-Private Partnerships and Community Law on Public Contracts and Concessions, European Commission Communication COM. 2004. 327 Final (April 2004)

8) Zakon o javno-privatnom partnerstvu i koncesijama Republike Srbije. 2011. Službeni glasnik RS, br. 88/11.

9) Zakon o izmenama i dopunama Zakona o javnoprivatnom partnerstvu i koncesijama Republike Srbije. 2016. Službeni glasnik RS, br. 15/2016.

10) European PPP Expertise Centre. 2014. PPP Unit and Related Institutional Framework Serbia.

11) European PPP Expertise Centre. 2019. Market update: Review of the European PPP Market in 2018.

12) Komisija za javno-privatno partnerstvo, Republika Srbija. 2019. Accessed 30. jun. http://www.ppp.gov.rs

13) European PPP Expertise Centre. 2019. Accessed 30. jun. https://www.eib.org/epec/index.htm

14) World Bank Group. 2014. Public-Private Partnerships: Reference Guide Version 2.0. World Bank Publications. The World Bank Group. 